\title{
PRODUCTION OF EXTRACELLULAR PROTEASES BY MUCOR CIRCINELLOIDES USING D-GLUCOSE AS CARBON SOURCE / SUBSTRATE
}

\author{
Vânia Sousa Andrade' ${ }^{1}$ Leonie Asfora Sarubbo² Kasutaka Fukushima $^{3}$; Makoto Miyajii ${ }^{3}$ Kazuko Nishimura ${ }^{3}$; \\ Galba Maria de Campos-Takaki ${ }^{2 *}$
}

\begin{abstract}
${ }^{1}$ Departamento de Patologia, Universidade Federal de Alagoas, Maceió, AL, Brasil. ${ }^{2}$ Departamento de Química, Núcleo de Pesquisas em Ciências Ambientais, Universidade Católica de Pernambuco, Recife, PE, Brasil. ${ }^{3}$ Research Center for Pathogenic Fungi and Microbial Toxicoses, Chiba University, Inohara, Chiba, Japan.
\end{abstract}

Submitted: February 15, 2001; Returned to authors for corrections: May 07, 2001; Approved: May 13, 2002

\begin{abstract}
Recently, some Mucorales species have been reported as protease producers. The production of extracellular proteases by Mucor circinelloides using glucose as substrate was studied. Experiments were carried out with different D-glucose concentrations $(40,60$ and $80 \mathrm{~g} / \mathrm{L})$. Biomass, $\mathrm{pH}$ and protease activity were determined. Although biomass production had reached best yields for the medium containing D-glucose in a concentration of $80 \mathrm{~g} / \mathrm{L}$, the enzymatic production was higher when the substrate concentration was reduced to $40 \mathrm{~g} / \mathrm{L}$. The yield factor for product on cell growth and the yield factor for product on carbon substrate were higher when the microorganism grew in medium containing $40 \mathrm{~g} / \mathrm{L}$ glucose. The kinetics parameters suggest that this strain seems to be promising as an alternative microorganism for protease production.
\end{abstract}

Key words: extracellular proteases, D-glucose, substrate, Mucor circinelloides.

\section{INTRODUCTION}

Microorganisms produce a large variety of enzymes, most of which are made in only small amounts and are involved in cellular processes. Extracellular enzymes are usually capable of digesting insoluble nutrient materials such as cellulose, protein and starch, and the digested products are transported into the cell where they are used as nutrients for growth $(12,18)$. Some extracellular enzymes are used in the food, dairy, pharmaceutical, and textile industries and are produced in large amounts by microbial synthesis $(1,2)$.

In the fungi of the order Mucorales, members of the genus Mucor occur typically as saprophytes in soil, and among them, M. miehei, M. pusillus and M. bacilliformis have been utilized in food industry and fermented beverage $(4,10,20)$.

Proteases are one of the most important groups of industrial enzymes and account for nearly $60 \%$ of the total enzyme sale
$(4,7)$. The major uses of free proteases occur in dry cleaning, detergents, meat processing, cheese making, silver recovery from photographic film, production of digestive and certain medical treatments of inflammation and virulent wounds (17). Although bacterial proteases have long been used in industry, the main drawback in their use is that they require cost-intensive filtration methodologies to obtain a microbe-free enzyme preparation. On the other hand, the proteases of fungal origin offer an advantage in that the mycelium can be easily removed by filtration (19).

Several reports describe the efficient protease biosynthesis by fungi belonging to the genera Aspergillus (8), Penicillium (5), Rhizopus (9), Humicola (1), etc. Two closely related species of Zygomycete fungus, Mucor pusillus and Mucor miehei, secrete aspartate proteases, also known as mucor rennins, into the medium. The enzymes possess high milk-clotting activity and low proteolytic activity, enabling them to be used as substitutes for calf chymosin in the cheese industry $(15,21)$.

\footnotetext{
* Corresponding author. Mailing address: Departamento de Química, Núcleo de Pesquisas em Ciências Ambientais, Universidade Católica de Pernambuco - UNICAP, Rua Nunes Machado, N.42, Bloco J, Térreo, Boa Vista, 50050-590, Recife, PE, Brasil. Phone: (+5581) 3216-4055, Fax: (+5581) 32164004, E-mail: takaki@unicap.br
} 
Investigations for protease production by many fungal cultures have shown that the producing amount of proteases varies greatly with the media used and regulatory effects exerted by the carbon sources have been described (18). Many experiments have been carried out with microorganisms cultivated with D-glucose as a substrate but there is little information about how the concentration and consumption of substrate affect enzyme production in Mucorales (7).

Few papers have been published about the variables that control the production of protease from Mucor $(7,15)$. It is not known how cell concentration and substrate consumption affect enzyme production. The rate of substrate consumption and its relationship to the previous variables are fundamental to determine the kinetics of the fermentation. Kinetic equations are basic for future bioreactor design and optimization.

The aim of this work was to investigate the protease production by $M$. circinelloides using D-glucose as substrate. To do so, process kinetic parameters were evaluated against different substrate concentrations. The relation between production and growth was analyzed to determine whether the enzyme is growth-associated, non-growth-associated or a mixture of growth associated and non-growth associated. The possibility of the enzyme being affected by feedback repression was also studied.

\section{MATERIALS AND METHODS}

\section{Microorganisms}

M. circinelloides IFM 40507 was obtained from the culture collection of the Research Center for Pathogenic Fungi and Microbial Toxicoses, Chiba University, Japan. The cultures were maintained on potato dextrose agar (Difco) slants at $4^{\circ} \mathrm{C}$. Every two months the cultures were transferred to new slants to keep them viable.

\section{Inoculum preparation}

M. circinelloides spores were harvested from cultures grown for 5-7 d in Petri dishes containing Difco's potato dextrose agar at $25^{\circ} \mathrm{C}$. A stock suspension was prepared and adjusted to $1.0 \mathrm{x}$ $10^{7}$ spores $/ \mathrm{mL}$, using a haemocytometer for counting. The solution was then stored at $4^{\circ} \mathrm{C}$.

\section{Fungal culture and growth conditions}

The cultures were grown in a synthetic medium previously described by Hesseltine and Anderson (14) which contains $40 \mathrm{~g} / \mathrm{LD}$-glucose, $2 \mathrm{~g} / \mathrm{L}$ asparagine, $0.005 \mathrm{mg} / \mathrm{L}$ thiamine, $0.5 \mathrm{~g} / \mathrm{L}$ potassium phosphate and $0.25 \mathrm{~g} / \mathrm{L}$ magnesium sulfate $(\mathrm{pH} 5.2)$. The concentration of D-glucose in media was varied from $40 \mathrm{~g} / \mathrm{L}$ to $80 \mathrm{~g} / \mathrm{L}$. All chemicals employed were of analytical grade. One $\mathrm{mL}$ of inoculum $\left(1.0 \times 10^{7}\right.$ spores/L) was transferred to $250 \mathrm{~mL}$ Erlenmeyer flasks containing $50 \mathrm{~mL}$ of the desired medium. The flasks were incubated at $25^{\circ} \mathrm{C}$ on a rotary shaker at $120 \mathrm{rpm}$. The mycelia were harvested by filtration through a silkscreen nylon filter. The biomass was lyophilized for 48 hours and kept under vacuum until constant weight. The supernatant was transferred to a penicillin flask for determination of $\mathrm{pH}$, protein and protease activity. The $\mathrm{pH}$ was measured in the culture supernatant during cultivation by using a glass-electrode $\mathrm{pH}$ meter.

\section{Analytical procedures}

Protease activity: The enzyme assay was based on the procedure described by Leighton et al. (16). Azoalbumin (Sigma, St. Louis, Mo) was dissolved as a $1 \%(\mathrm{w} / \mathrm{v})$ solution in $0.1 \mathrm{M}$ acetate buffer, $1.0 \mathrm{mM} \mathrm{CaCl}_{2}, \mathrm{pH} 4.5$. The solution was stored at $-20^{\circ} \mathrm{C}$. A $0.4 \mathrm{~mL}$ reaction mixture contained $250 \mu \mathrm{L}$ of azoalbumin solution and $150 \mu \mathrm{L}$ supernatant fraction. The reaction was terminated by the addition of $1.2 \mathrm{~mL}$ of $10 \%(\mathrm{w} / \mathrm{v})$ trichloroacetic acid. The reaction tubes were cooled at $0^{\circ} \mathrm{C}$ for $15 \mathrm{~min}$ and centrifuged to remove the precipitated protein. The supernatant $(0.8 \mathrm{~mL})$ was mixed with $1.4 \mathrm{~mL}$ of $1 \mathrm{~N} \mathrm{NaOH}$ and the absorbance read at $440 \mathrm{~nm}$. Units of proteolytic activity were expressed as $\mathrm{mg}$ of azoalbumin hydrolyzed per hour. Specific activity was calculated by the ratio between total protease activity and total protein concentration in $1 \mathrm{~mL}$ of sample $(\mathrm{U} / \mathrm{mg})$. The extracellular protein content was determined according to the method of Bradford (3). Bovine serum albumin (Sigma Chemical Co., St. Louis, Mo., U.S.A.) was used as the standard.

Glucose concentration: The glucose in the media was estimated by the Glucose Oxidase Method, according to Hanson and Phillips (13).

\section{Statistical procedures}

In all experiments, the measurements were carried out with duplicated parallel cultures. The values reported are means \pm S.D, calculated as described by Snedecor and Cochran (24).

\section{RESULTS AND DISCUSSION}

The results obtained in this work revealed the ability of $M$. circinelloides to produce extracellular proteases. Fig. 1 (A, B, and $\mathrm{C}$ ) shows the curves of growth, medium $\mathrm{pH}$, D-glucose concentration and specific protease activity, produced in the culture medium for different D-glucose concentrations. Although the cultivation media had different substrate concentrations, the growth curves, in a general mode, showed a similar profile. It could be observed that the sporic germination time reached almost 16 hours of cultivation. Probably, this improductive period could be avoided by the use of a more concentrate inoculum. This strategy must be considered for large scale applications.

Growth of the mycelia increased rapidly in the early stages and an increase on biomass production occurred when Dglucose concentration was altered in the media cultivation. For the medium containing D-glucose in a concentration of $80 \mathrm{~g} / \mathrm{L}$, 

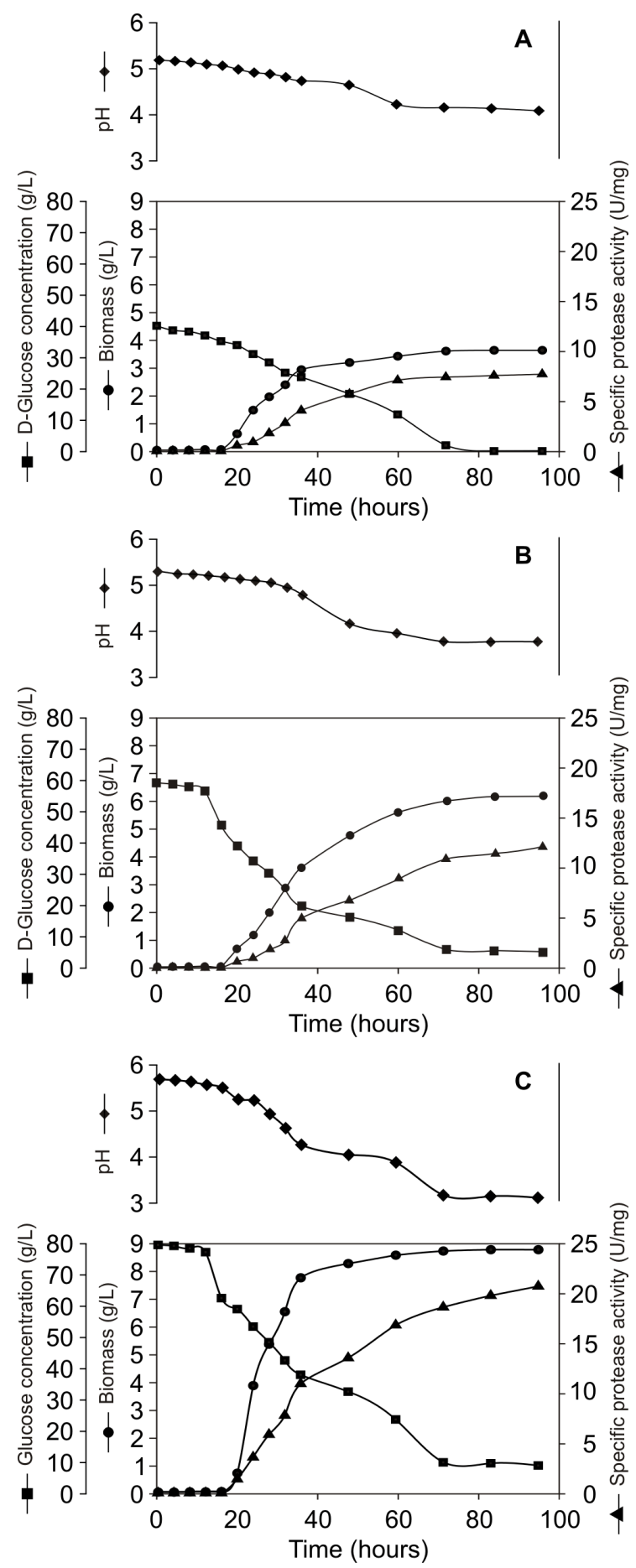

Figure 1. Extracellular protease production by $\mathrm{Mucor}$ circinelloides IFM 40507 in culture medium containing: 40 (A), 60 (B) and 80g D-glucose/L (C). (-) Biomass; (-) D-glucose concentration; $(-\mathbf{-})$ Specific protease activity; $(-\mathbf{-}) \mathrm{pH}$. The values represent averages of duplicates experiments, which were not significantly different $(p>0.05)$ from one another (biomass, $\mathrm{pH}$ and specific protease activity). the mycelial mass concentration was higher than those obtained in media containing $40 \mathrm{~g} / \mathrm{L}$ and $60 \mathrm{~g} / \mathrm{L}$ D-glucose as shown in Fig. 1. In the media containing higher D-glucose concentrations $(60 \mathrm{~g} / \mathrm{L}$ and $80 \mathrm{~g} / \mathrm{L})$, it was observed that the substrate was not totally consumed, in opposition to the medium with $40 \mathrm{~g} / \mathrm{L}$ Dglucose, where no remaining substrate was detected at the end of cultivation ( 96 hours of growth).

The $\mathrm{pH}$ decreased in the period of enzyme synthesis, and stayed relatively constant up to the end of fermentation. The low $\mathrm{pH}$ values observed at the end of cultivation were, probably, consequence of metabolites accumulation resulting from Dglucose degradation as low $\mathrm{pH}$ values (3.95 and 3.15) were observed in media containing higher D-glucose concentrations of $60 \mathrm{~g} / \mathrm{L}$ and $80 \mathrm{~g} / \mathrm{L}$, respectively.

To investigate the efficiency of filamentous fungus Mucor circinelloides on protease production, for three experimental conditions, the process response factors were calculated and are described in Table 1.

The substrate utilized allowed the microorganism to reach the exponential growth phase, where the micelial specific growth rates $\left(\mu_{\mathrm{x}}\right)$ were similar for the three glucose concentrations studied.

An important factor is the repression of product formation either by other metabolites or by the main product itself. Kinetically speaking, this behavior is found when the rate of product formation decreases when the substrate concentrations increase (7). In our case, the biomass production increased with glucose concentration as shown in Fig.1 (A, B and C), although the yield factor for product on substrate consumed $\left(\mathrm{Y}_{\mathrm{P} / \mathrm{S}}\right)$ decreased with glucose concentration (Table 1).

The results obtained here suggest a possible glucose regulation by catabolic repression over the enzymatic production, which can be attributed to the presence of high substrate concentration $(80 \mathrm{~g} / \mathrm{L})$. This observation is supported by the fact that the yield factor for product on substrate consumed $\left(\mathrm{Y}_{\mathrm{P} / \mathrm{S}}\right)$ decreased while the yield factor for cell on substrate $\left(\mathrm{Y}_{\mathrm{X} / \mathrm{S}}\right)$ increased. According to our observations, Dekleva et al. (6) described the possibility of these proteases to be repressed by D-glucose remaining in the medium. In contrast, recent investigations showed that protease from Streptomyces ambofaciens was detected only after glucose depletion (2).

It has been frequently described that in a defined medium, a protein source must be present for the enzyme to be produced. However, it has been also noticed that the lack of glucose results in a dramatic decrease in enzyme production. Glucose has been reported to suppress protease production $(22,25)$, but in the present study it was found to be a relatively good substrate for enzyme production, specially when used at low concentrations $(40 \mathrm{~g} / \mathrm{L})$. Other workers have also reported better protease production in the presence of glucose as a substrate (11).

Phadatare et al. (19) evaluated various sugars such as glucose, fructose, lactose, maltose, sucrose, xylose, and sugar alcohols, glycerol, mannitol, and sorbitol (1-5\%, w/v) for their effect on 
Table 1. Process response factors of extracellular proteases production from Mucor circinelloides.

\begin{tabular}{|c|c|c|c|c|c|}
\hline \multirow[b]{2}{*}{$\begin{array}{c}\text { Substrate } \\
\text { concentration } \\
(\mathrm{g} / \mathrm{L})\end{array}$} & $Y_{X / S}(g / g)$ & $Y_{P / S}(U / g)$ & $Y_{P / X}(U / g)$ & $\mathbf{Q}_{P}(\mathrm{U} / \mathrm{L} . \mathbf{h})$ & $\mu x\left(h^{-1}\right)$ \\
\hline & $\begin{array}{c}\text { Yield factor for } \\
\text { biomass on substrate } \\
\text { consumed }\end{array}$ & $\begin{array}{c}\text { Yield factor for } \\
\text { product on substrate } \\
\text { consumed }\end{array}$ & $\begin{array}{l}\text { Yield factor for } \\
\text { product on } \\
\text { biomass }\end{array}$ & $\begin{array}{l}\text { Volumetric } \\
\text { productivity }\end{array}$ & $\begin{array}{l}\text { Maximum } \\
\text { specific } \\
\text { growth rate }\end{array}$ \\
\hline 60 & 0.11 & 0.22 & 1.92 & 4.36 & 0.10 \\
\hline 80 & 0.12 & 0.14 & 1.11 & 3.59 & 0.13 \\
\hline
\end{tabular}

Values represent the mean of duplicate determinations of duplicate experiments. The standard deviations were less than $1.8 \%$.

enzyme production. The results obtained revealed that sucrose $(3 \% \mathrm{w} / \mathrm{v})$ gave the maximum protease activity of $0.5 \mathrm{U} / \mathrm{mL}$. Yang et al. (26) studied the effect of carbon sources on the production of protease by Bacillus subtillis growing in shrimp and crab shell powder medium containing one of the additional carbon sources: glucose, lactose, carboxymethyl cellulose, D(-)arabinose, $\mathrm{D}(+)$ xylose, and rice bran. They found that protease production was greatly enhanced by the addition of lactose or arabinose into the medium and that $1 \%$ arabinose was the most effective substrate and concentration for protease production.

Another important point would be the energetic stock proportionate to the microorganism by glucose and/or other substrates which can favor and regulates the extracellular protease synthesis by $M$. circinelloides. The evidence that extracellular protease regulation may be dependent on the energetic stock of the cell was described in Pseudomonas aeruginosa (28) and Aspergillus nidulans (18).

Aleksieva and Peeva (1) found that protease production was growth associated when using the fungus Humicola lutea cultivated in a medium containing glucose at low concentration $(30 \mathrm{~g} / \mathrm{L})$. Similarly, the kinetic pattern found in this work describes a growth associated to the product formation for 40 $\mathrm{g} / \mathrm{L}$ of substrate since the product is produced simultaneously to microbial growth (Fig. 1A). However, for higher substrate concentrations, the growth is typically semi-associated since product formation takes place during the growth and stationary phases (Fig. 1B and 1C), as described in the literature $(23,27)$.

Considering the interest of this study in evaluate protease production from Mucor circinelloides, it is not advantageous, for economic application, utilize high glucose concentrations, since the best enzymatic yield occurred for the lowest substrate concentration, as showed either by the $\mathrm{Y}_{\mathrm{P} / \mathrm{X}}$ and $\mathrm{Y}_{\mathrm{P} / \mathrm{S}}$, and by the volumetric production factor $\left(\mathrm{Q}_{\mathrm{P}}\right)$ which was basically the same for three substrate concentrations studied (Table 1).

Various microorganisms and cultivation media have been studied for protease production (12). The results presented here show that $M$. circinelloides is a promising alternative source of protease, exhibiting volumetric production factor of approximately 4.6 U/L.h.

From the different data accumulated in this research, there was a strong indication that the kinetics factors reported here could serve as a starting point for an experimental optimization of $M$. circinelloides growth for large-scale protease production. Further studies are in progress to investigate the physiological significance of the protease in relation to the microorganism.

\section{ACKNOWLEDGEMENTS}

This study received financial support from the Brazilian agencies Fundação Coordenação de Aperfeiçoamento de Pessoal de Nível Superior (CAPES), Conselho Nacional de Desenvolvimento Científico e Tecnológico (CNPq) and Programa de Apoio a Núcleos de Excelência (PRONEX). The authors gratefully thank Severino Humberto de Almeida for technical assistance during this work.

\section{RESUMO}

\section{Produção de proteases extracelulares por $\mathbf{M u c o r}$ circinelloides utilizando D-glicose como substrato}

Recentemente, algumas espécies da ordem Mucorales têm sido reportadas como produtoras de proteases. Neste trabalho a produção de proteases extracelulares foi estudada em uma amostra de Mucor circinelloides utilizando D-glicose, em diferentes concentrações (40, 60 e $80 \mathrm{~g} / \mathrm{L})$, como substrato. A fermentação foi acompanhada com determinação de biomassa e $\mathrm{pH}$, assim como pela determinação da atividade proteásica. Embora a produção de biomassa tenha alcançado melhores rendimentos na presença de $80 \mathrm{~g} / \mathrm{L}$ de glicose, a produtividade enzimática aumentou quando a concentração do substrato foi reduzida para $40 \mathrm{~g} / \mathrm{L}$. Os fatores de rendimento de produção enzimática por biomassa, assim como o rendimento de glicose consumida em atividade proteásica foram superiores quando o cultivo do microrganismo ocorreu em meio contendo $40 \mathrm{~g} / \mathrm{L} \mathrm{de}$ D-glicose. As variáveis de resposta do bioprocesso sugerem que a linhagem estudada possa ser utilizada como microrganismo agente para a produção de protease.

Palavras-chave: proteases extracelulares, D-glicose, substrato, Mucor circinelloides. 


\section{REFERENCES}

1. Aleksieva, P.; Peeva, L. Investigation of acid proteinase biosynthesis by the fungus Humicola lutea $120-5$ in an airlift bioreactor. Enzyme Microb. Technol., 26: 402-405, 2000.

2. Benslimane, C.; Lebrihi, A.; Lounes, A.; Lefebvre, G.; Germain, P. Influence of dextrins on the assimilation of yeast extract amino acids in culture of Streptomyces ambofaciens producer of spiramycin. Enzyme. Microb. Technol., 17: 1003-1013, 1995.

3. Bradford, M.M. A rapid and sensitive method for the quantitation of microgram quantities of protein utilizing the principle of proteindye binding. Anal. Biochem., 72: 248-254, 1974.

4. Brown, E.D.; Yada, R.Y. Spin-labelling and differential scanning colorimetry study of the denaturation of aspartic proteinases from the fungi Endhotia parasitica and Mucor. miehei. Agric. Biol. Chem., 55: 1639-1641, 1991.

5. Chrzanowska, J.; Kolaczkowska, M.; Polanowski, A. Production of exocellular proteolytic enzymes by various species of Penicillium. Enzyme Microb. Technol., 15: 140-143, 1993.

6. Dekleva, M.L.; Titus, J.A.; Strohl, W.R. Nutrient effects on anthracycline production by Streptomyces peucetius in a defined medium. Can. J. Microbiol., 31: 287-294, 1985.

7. Escobar, J.; Barnett, S.M. Effect of agitation speed on the synthesis of Mucor miehei acid protease. Enzyme Microb. Technol., 15: 10091013, 1993 .

8. Fan-Ching, Y; Lin, I.H. Production of acid protease using thin stillage from a rice-spirit distillery by Aspergillus niger. Enzyme Microb. Technol., 23: 397-402, 1998.

9. Farley, P.C.; Ikasari, L. Regulation of the secretion of Rhizopus Oligosporus extracellular carboxyl proteinase. J. Gen. Microbiol., 138: 2539-2544, 1992.

10. Fernández-Lahore, H.M.; Miranda, M.V.; Fraile, E.R.; Bonono, M.J.B.J.; Cascone, O. Partition behaviour and purification of a Mucor bacilifformis acid protease in aqueous two-phase systems. Proc. Biochem., 30: 615-621, 1995.

11. Gajju, H.; Bhalla, T.C.; Agarwal, H.O. Thermostable alkaline protease from thermophilic Bacillus coagulans PB-77. Ind. J. Microbiol. 36: 153-155, 1996.

12. Gibb, G.D.; Strohl, W.R. Physiological regulation of protease activity in Streptomyces peucetius. Can. J. Microbiol., 34: 187-190, 1987.

13. Hanson, R.S.; Phillips, J.A. Chemical composition. In: Gerhardt, P.; Murray, R.G.E.; Costilow, R.N. et al. (eds). Manual of Methods for General Bacteriology. American Society for Microbiology, Washington, 1981, p.328-364.
14. Hesseltine, C.W.; Anderson, R.P. Microbiological production of carotenoids. I. Zygospores and carotene produced by intersepecific and crosses of Choanephoraceae in liquid media. Mycologia, 49: 449-452, 1957

15. Lasure, L.L. Regulation of extracellular acid protease in Mucor miehei. Mycologia, 72: 483-493, 1980.

16. Leighton, T.J.; Doi, R.H.; Warren, R.A.J.; Kelln, R.A. The relationship of serine protease activity to RNA polymerase modification and sporulation in Bacillus subtilis. J. Mol. Biol., 76: 103-122, 1973.

17. Nout, M.J.R.; Rombouts, F.M. Recent developments in tempe research. J. Appl. Bacteriol., 69: 609-633, 1990.

18. Oh, Y.S.; Shih, I.L.; Tzeng, Y.M.; Wang, S.L. Protease produced by Pseudomonas aeruginosa K-187 and its application in the deproteinization of shrimp and crab shell wastes. Enzyme Microb. Technol., 27: 3-10, 2000.

19. Phadatare, S.U.; Deshpande, V.V.; Srinivasan, M.C. High activity alkaline protease from Conidiobolus coronatus (NCL 86.8.20). Enzyme production and compatibility with commercial detergents. Enzyme Microb. Technol., 15: 72-76, 1993.

20. Prakask, R.; Sarbboy, A.K. Food fermentation products induced by Mucorales. J. Mycopathol. Res., 31: 49-55, 1993.

21. Rao, M.B.; Tanksale, A.M.; Ghatge, M.S.; Deshpande, V.V. Molecular and biotechnological aspects of microbial proteases. Microbiology and Molecular Biology Reviews, 62: 597-635, 1998.

22. Sen, S.; Satyanarayana, T. Optimization of alkaline protease production by thermophilic Bacillus licheniformis S-40. Ind. J. Microbiol., 33: 43-47, 1993.

23. Sinclair, C.G.; Cantero, D. Fermentation modelling. In: McNeil, B. and Harvey, L.M. (eds.). Fermentation: a practical approach. IRL Press, Glasgow, UK, 1990, pp.65-112.

24. Snedecor, G.W. and Cochran, W.G. Statistical Methods. Lowa State University Press, Ames, IA. 1980, 428p.

25. Sonnleitner, B. Biotechnology of thermophilic bacteria growth, products and application. In: Fiechter, A. (ed.). Adv. Biochem. Biotechnol. Springer, Berlin, 1983, p.70-138.

26. Yang, J.K.; Shih, I.L.; Tzeng, Y.M.; Wang, S.L. Production and purification of protease from a Bacillus subtilis that can deproteinize crustacean wastes. Enzyme Microb. Technol., 26: 406-413, 1999.

27. Wang, D.; Cooney, C.; Demain, A.; Dunnill, P. Fermentation and Enzyme Technology. John Wiley \& Sons, New York, 1978, p.78-81.

28. Whooley, M.A.; O'Callaghan, J.A.; McLoughlin, A.J. Effect of substrate on the regulation of exoprotease production by Pseudomonas aeruginosa ATCC 10145. J. Gen. Microbiol., 129: 981-988, 1983 . 